\title{
(IN)SEGURANÇA HÍDRICA E O DESAFIO DE PRODUZIR SEM ACESSO À ÁGUA EM ASSENTAMENTOS DE REFORMA AGRÁRIA DO MUNICÍPIO DE UBERLÂNDIA-MG
}

\section{HYDRIC (IN)SECURITY AND THE CHALLENGE OF PRODUCING WITHOUT ACCESS TO WATER IN SETTLEMENTS OF AGRARIAN REFORM UBERLÂNDIA-MG}

\section{(IN)SEGURIDAD DEL AGUA Y EL RETO DE PRODUCIR SIN ACCESO A AGUA EN ASENTAMIENTOS DE REFORMA AGRARIA DEL CONDADO DE UBERLÂNDIA-MG}

\section{Jéssica Cristina Garcia ${ }^{1}$ João Cleps Junior ${ }^{2}$}

\begin{abstract}
RESUMO: Na atualidade, a questão da água vem ganhando destaque, não apenas nas mídias, mas também no que diz respeito à regulamentação de políticas públicas. É notório que os debates em torno da sustentabilidade ambiental são de suma importância, sobretudo, quando se leva em consideração a produção agrícola e a qualidade de vida dos agricultores e da população que consome o que é produzido no campo. No entanto, as políticas públicas destinadas ao espaço rural comumente priorizam o agronegócio, em detrimento da agricultura camponesa, que atualmente se afirma nos movimentos sociais de luta pela terra e para sua permanência nela. Com documentos que regulam e legitimam a exploração da natureza em áreas demarcadas pelo Estado (assentamentos rurais), os camponeses muitas vezes não conseguem extrair da terra o necessário para seu próprio sustento, pois o aspecto ambiental acaba sendo priorizado, em detrimento da produção agrícola dos assentados. Dessa forma, é importante atentar para o Plano de Desenvolvimento de Assentamento (PDA), pois é nele que estão as alternativas para a consolidação ou não de um projeto de assentamento de reforma agrária, assim como a questão do uso e acesso à água, que tem se tornado um entrave à produção agrícola e à qualidade de vida da população dos assentamentos rurais, visto que a falta de água para a produção agrícola constitui uma das maiores barreiras para consolidação desses assentamentos. É caso de quatro projetos de assentamentos rurais do município de Uberlândia-MG.
\end{abstract}

Palavras-chave: sustentabilidade, assentamentos de reforma agrária, insegurança hídrica, Uberlândia-MG.

\footnotetext{
1 jessicacrisis@yahoo.com.br Universidade Federal de Uberlândia

2 jcleps@ufu.br Universidade Federal de Uberlândia
} 
ABSTRACT: At the present, the issue of water has been gaining attention not only in the media, but also with regard to the regulation of public policies. It is clear that debates about environmental sustainability is of paramount importance, especially, when taking into account agricultural production and the quality of life of farmers and the population who consumes what is grown in the field. However, public policies aimed at the field often give priority to agribusiness at the expense of the peasant agriculture, which presently maintains itself through social movements that struggles for land and their permanence in it. With documents that regulate and legitimize the exploitation of nature in areas marked by the State (rural settlements) the peasants often fail to extract of the land what is necessary to support themselves, as the environmental aspect ends up being prioritized at the expense of agricultural production settlers. Thus, it is important to pay attention to the Settlement Development Plan (PDA - Plano de Desenvolvimento de Assentamento), because it is where the options are for the consolidation or not of an agrarian reform settlement project as well as the question of the use and access to water, which has become an obstacle to agricultural production and quality of life of rural settlements, since, the lack of water for agricultural production is one of the biggest barriers to the consolidation of an agrarian reform settlement, as is the case of four rural settlements projects in the county Uberlândia-MG.

Keywords: Sustainability, land reform, water insecurity, Uberlândia-MG.

RESUMEN: En la actualidad, la cuestión de la agua está ganando importancia, no sólo en los medios de comunicación, sino también en lo que respecta a la regulación de las políticas públicas. Está claro que los debates sobre la sostenibilidad del medio ambiente son de suma importancia, sobre todo si se tiene en cuenta la producción agrícola y la calidad de vida de los agricultores y de la población que consume lo que se produce en el campo. Sin embargo, las políticas públicas dirigidas al campo común priorizar los agronegocios a costa de la agricultura campesina, que mantiene en la actualidad a través de los movimientos sociales que luchan por la tierra y su estancia en el mismo. Con los documentos que regulan y legitiman la explotación de la naturaleza en las zonas delimitadas por el Estado (asentamientos rurales), los agricultores a menudo no logran extraer la tierra necesaria para mantenerse a sí mismos como el aspecto ambiental termina siendo priorizado a expensas de la producción agrícola colonos. Por lo tanto, es importante prestar atención al Plan de Desarrollo de Asentamiento (PDA), porque es donde están las alternativas para la consolidación de un proyecto de asentamiento de reforma agraria, así como la cuestión del uso y el acceso al agua, que se ha convertido en un obstáculo a la producción agrícola y la calidad de vida de las poblaciones rurales, ya que la falta de agua para la producción agrícola es uno de los mayores obstáculos a la consolidación de la reforma agraria, como es el caso de los cuatro proyectos de asentamientos rurales en el municipio Uberlândia-MG

Palabras clave: Sostenibilidad, reforma agraria, inseguridad del agua, Uberlândia-MG. 


\section{INTRODUÇÃO}

A temática do uso da água na atualidade vem promovendo inúmeros debates e opiniões diversas. Com a expansão das técnicas do sistema capitalista de produção, os bens naturais são cada vez mais explorados e quem tem controle sobre o território onde esses bens se encontram tem também o poder de decisão e gestão sobre os mesmos. O uso da água para fins econômicos gera conflitos, pois alguma entidade se apropria desse recurso, que é um bem natural, e acaba transformando-o em recurso hídrico, um bem pago.

Na mesorregião do Triângulo Mineiro, uma área de intensa produção agrícola dominada pelo agronegócio - principalmente para a produção de commodities - e que possui diversas barragens, o uso da água tornou-se um privilégio daqueles que têm condições financeiras de pagar para dela usufruir, enquanto os mais pobres são excluídos e acabam se deslocando para outras áreas do território.

Neste artigo, buscamos sistematizar os dados sobre as condições socioambientais e, em específico, sobre o problema da água dos Projetos de Assentamento (PAs) de Uberlândia ${ }^{3}$. A opção pela seleção de comunidades de agricultores beneficiados pelos projetos de reforma agrária se justifica pela identificação e carência de ações públicas que mobilizem e orientem os pequenos produtores diante do problema da água. Através dos estudos de campo e referencial bibliográfico, percebe-se que a dificuldade de acesso ao recurso hídrico em assentamentos rurais não está diretamente relacionada com uma possível escassez de água, mas também está inteiramente conectada com as diferentes formas de interação da população com o meio e seus sistemas e saberes locais, com as formas de apropriação e gestão da

\footnotetext{
${ }^{3}$ Este artigo é resultado de pesquisas apoiadas pelo Programa Institucional de Bolsas de Iniciação em Desenvolvimento Tecnológico e Inovação - PIBITI/CNPq/UFU (2012-2013), e pelo Programa de Extensão Integração UFU/Comunidade da Pró-Reitoria de Extensão, Cultura e Assuntos Estudantis - PROEX-UFU. O projeto PIBITI denominou-se "Inovações Tecnológicas e Práticas de Gestão da Água na Agricultura em Projetos de Reforma Agrária no Triângulo Mineiro/Alto Paranaíba", sob a coordenação do Prof. Dr. João Cleps Jr.
} 
natureza, e também com a presença de atores econômicos rurais, de forma a influenciar diretamente no desenvolvimento de suas atividades. Assim, é preciso atentar para o fato de que os órgãos governamentais acabam, também, sendo responsáveis por orientar e determinar os destinos da produção e o sucesso dos agricultores na medida em que disponibilizam, ou não, os recursos necessários para que os assentados possam usufruir desse bem natural de uma maneira sustentável e economicamente viável.

Inicialmente, discutimos, em termos práticos, sobre o instrumento básico para o desenvolvimento e implantação inicial dos assentamentos rurais que é o Plano de Desenvolvimento de Assentamento (PDA), além da assistência técnica e o financiamento público das infraestruturas físicas para os assentados. Também são abordadas as correntes interpretativas sobre a questão do desenvolvimento econômico e apropriação da natureza no contexto das contradições do modelo econômico vigente. No item seguinte, são abordadas as questões centrais do uso e apropriação da água no contexto local, com ênfase no processo de desenvolvimento agrícola dos cerrados e os conflitos socioambientais regionais no contexto da questão agrária brasileira. Por fim, são analisadas as situações dos projetos de assentamentos em Uberlândia-MG (PAs Florestan Fernandes, Zumbi dos Palmares, Nova Tangará e Dom José Mauro) e os desafios em produzir a partir das insuficiências e da problemática da água. Mostraremos, com base em pesquisas de campo, um pouco da realidade perversa que atinge as áreas de agricultura camponesa e familiar buscando ressaltar um pouco das práticas sustentáveis como alternativa à agricultura capitalista e ao modelo do agronegócio.

\section{- plano de desenvolvimento de assentamento como DOCUMENTO NORTEADOR DA CONSOLIDAÇÃO DOS ASSENTAMENTOS RURAIS}

A implementação de um Projeto de Assentamento passa por várias etapas, seguindo as diretrizes que levam à consolidação do processo de reforma agrária. O Instituto Nacional de Colonização e Reforma Agrária (Incra) é o órgão responsável pelo levantamento e apropriação das terras 

Assentamentos de Reforma Agrária do Município de Uberlândia-MG, pp. 63-94

improdutivas, com finalidade de destiná-las à reforma agrária. O órgão realiza o cadastro das famílias, o registro em cartório do assentamento, o estudo da capacidade e a distribuição dos lotes.

Após esses procedimentos, inicia-se a etapa de consolidação do PA por meio de projetos e programas de desenvolvimento, baseados em um estudo minucioso e detalhado de todas as potencialidades físico-naturais, sociais e ecológicas do assentamento, reunidos em um documento de suma importância para o direcionamento das políticas públicas, que é o Plano de Desenvolvimento do Assentamento, sendo este o documento que norteará as ações empreendidas nos assentamentos rurais, assim como a exploração dos recursos naturais visando ao desenvolvimento socioeconômico e assegurando a sua sustentabilidade.

A construção do PDA deve partir de um diagnóstico inicial da realidade da área onde está sendo implantado o assentamento e os seus programas vão reunir diferentes ações que têm por finalidade 0 desenvolvimento socioeconômico do PA, como:

- Organização do espaço por meio do anteprojeto de parcelamento: como e onde vão ser instaladas áreas de moradia, produção, reserva e preservação florestal, equipamentos de uso comunitário, vias de acesso, obras e se o assentamento vai ser organizado de forma individual, coletiva ou mista;

- Programa de produção: quais atividades produtivas serão desenvolvidas respeitando-se as expectativas e experiências das famílias assentadas, e também as viabilidades técnica, econômica e financeira;

- Programa de gestão ambiental: o que será feito para recuperar, conservar e preservar o meio ambiente, e as ações na área da educação ambiental;

- Programa social: envolve as atividades relacionadas a saúde, educação, lazer, esporte, cultura e desenvolvimento comunitário;

- Programa de obras e infraestrutura básica: define as obras necessárias e sua localização;

- Modelo de gestão: como serão executados os programas e atividades, a participação das famílias, do órgão, do Estado e dos municípios (INCRA, 2001). 
Ao criar um projeto de assentamento, o Incra deve atentar não apenas à legislação agrária, mas também à legislação ambiental. É pela utilização adequada dos elementos existentes na natureza que será assegurada a sustentabilidade do assentamento. Além do plano de desenvolvimento do assentamento, a área precisa ter o licenciamento ambiental concedido pelo órgão ambiental de cada Estado (INCRA, 2001).

Existe um estudo local e regional a respeito de onde o PA estará localizado, objetivando integrar os assentados na comunidade circunvizinha, fazendo com que eles produzam para o autoconsumo e vendam os excedentes (ALBUQUERQUE; COELHO; VASCONCELOS, 2004).

O estudo das riquezas naturais regionais leva em consideração a heterogeneidade ecológica, que vai condicionar diferentes atividades agrícolas. Na agricultura, existe uma diversidade de formas de produção e tipos de agricultores, sobretudo quando se considera a agricultura familiar e os assentados de reforma agrária, pois nem todos apresentam o mesmo nível de capitalização, a mesma forma de acesso à terra, à natureza, aos financiamentos e aos serviços públicos, e tampouco o mesmo modo de se organizar e de se relacionar com os outros agentes sociais (INCRA, 1999).

O objetivo da realização de um levantamento minucioso de todas as potencialidades de cada PA é propor projetos de desenvolvimento compatíveis com a realidade e a expectativa dos assentados. As atividades que serão desenvolvidas dependerão das características físicas e sociais presentes no assentamento e nas condições das famílias assentadas.

É importante considerar que, apesar de esse estudo ser um documento de suma importância para nortear o desenvolvimento dos PAs, muitos assentamentos estão apresentando divergências entre o que está estipulado no PDA e a realidade local. Como se observou em campo, alguns estudos não condizem com a realidade presenciada nos assentamentos. A falta de diálogo entre o técnico que faz o levantamento e a população assentada representa o maior empecilho na formulação de documentos específicos para os assentamentos rurais, além de desfavorecer modos de vida e de produção agrícolas tradicionais.

A ausência de assistência técnica e estudos detalhados do meio 

Assentamentos de Reforma Agrária do Município de Uberlândia-MG, pp. 63-94

inviabilizam a produção e a autossuficiência do assentamento. A ausência de vias de acesso às sedes dos municípios acaba impossibilitando a comercialização dos produtos, o que acarreta diminuição na renda dos assentados e dificuldade de investir no melhoramento da produção. Assim, inúmeros assentados acabam desistindo da terra e se dirigindo para os centros urbanos, reproduzindo a miséria e a exclusão existentes nas grandes cidades.

Para sanar essa lacuna existente entre os elaboradores dos PDAs e os assentados, foi criado, em 2003, o Programa de Assistência Técnica Social e Ambiental (ATES), que se ligaria, posteriormente, à Política Nacional de Assistência Técnica e Extensão Rural (PNATER) ${ }^{4}$, sendo sua assessoria prevista no Plano Plurianual do Governo Federal como uma ação orçamentária integrante do Programa de Assistência Técnica e Extensão Rural na Agricultura Familiar, visando implantar um processo descentralizado de apoio às famílias dos(as) camponeses assentados(as) em projetos de assentamento criados ou reconhecidos pelo Incra (INCRA, 2008). O programa tem como finalidade assessorar técnica, social e ambientalmente as famílias nos projetos de assentamentos, tornando-os unidades produtivas estruturadas, com garantia à segurança alimentar e participantes no processo de desenvolvimento nas esferas municipal, regional e territorial com sustentabilidade.

A ATES é executada em parceria com instituições públicas, privadas, entidades de representação dos trabalhadores e trabalhadoras rurais, e organizações não-governamentais (ONGs) ligadas à reforma agrária (INCRA, 2008).

Dentre as instâncias de supervisão e coordenação do programa estão o Incra, a Diretoria de Desenvolvimento de Projetos de Assentamento (DD) e as Superintendências Regionais (SR), sendo estas as responsáveis pela elaboração dos PDAs, entre outras atribuições, conforme estabelecido:

\footnotetext{
4 A Política Nacional de Assistência Técnica e Extensão Rural para a Agricultura Familiar e Reforma Agrária (PNATER) e o Programa Nacional de Assistência Técnica e Extensão Rural na Agricultura Familiar e na Reforma Agrária (Pronater) foram instituídos pela Lei No 12.188, de 11 de janeiro de 2010.
} 
Caberá à Superintendência Regional [...] celebrar convênios, contratos, termos de parceria e demais instrumentos congêneres com órgãos e entidades que trabalhem com a temática de desenvolvimento rural sustentável para execução das atividades de ATES, elaboração e implementação do Projeto de Exploração Anual (PEA), do Plano de Desenvolvimento do Assentamento (PDA), do Plano de Recuperação do Assentamento (PRA) e do Relatório Ambiental Simplificado (RAS) [...]. (INCRA, 2008, p. 20.)

Percebemos, assim, a importância do PDA para os assentamentos, visto que sua elaboração está sujeita a uma política nacional de assistência técnica e desenvolvimento rural.

Desta forma, o Plano de Desenvolvimento de Assentamento atua como um instrumento norteador dos projetos a serem desenvolvidos no PA, assegurando que eles sejam coerentes com a realidade local e sociocultural dos seus assentados, proporcionando a permanência do homem no campo. É importante destacar que os PDAs devem ser formulados juntamente com os assentados para evitar distorções da realidade e das vontades da população que ali se encontra.

Além disso, existe a questão da sustentabilidade do assentamento. Não devemos confundir os conceitos de sustentabilidade e desenvolvimento sustentável, pois, apesar de serem utilizados, comumente, para representar a "preocupação" dos agentes econômicos com a exploração da natureza, são conceitos que partem de correntes teóricas distintas, a saber, as correntes ecotecnocrática e ecossocial ${ }^{5}$.

A corrente ecotecnocrática parte do pressuposto que a adoção de tecnologia em todas as etapas produtivas pode minimizar os danos causados à natureza. Essa corrente, pautada nos ideais do neoliberalismo, pressupõe que - mercado seja capaz de regular não apenas a economia, mas também a apropriação da natureza, aqui entendida como matéria-prima. Na agricultura, tal corrente difunde o uso maciço de tecnologias como os insumos industrializados e as sementes selecionadas, a fim de construir uma alta produtividade em um determinado lugar e, assim, evitar que outras áreas sejam devastadas para produção de alimentos. A Revolução Verde das

\footnotetext{
${ }^{5}$ Não pretendemos aqui discutir em profundidade as formulações propostas por tais correntes; contudo, é salutar esclarecer que esses conceitos, utilizados indistintamente, representam interesses distintos quanto à apropriação da natureza.
} 
décadas de 1960 e 1970 é exemplo da ideologia da corrente ecotecnocrática. No entanto, tal ideologia não chega a se preocupar com preservação ou conservação da biodiversidade; há apenas uma tentativa de "esverdeamento" da produção por meio de empresas que difundem o slogan de ambientalmente responsáveis.

Já a corrente ecossocial parte da crítica à corrente liberal - sobretudo, da crítica ao mercado -, por sua incapacidade de responder tanto aos desafios da pobreza como aos desafios ambientais. As questões ambientais e sociais fazem parte do marco teórico dos ecossocialistas, que também sugerem estratégias alternativas não apenas no que se refere à organização do trabalho, como também às formas de produção e comercialização.

Além disso, Caporal e Costabeber (2000) salientam que esta corrente

Defende um desenvolvimento que respeite os distintos modos de vida e as diferentes culturas e que favoreça a preservação da biodiversidade. Em síntese, propõem uma mudança no sistema e nas orientações econômicas dominantes em favor de novas estratégias que, baseadas na descentralização dos processos produtivos, sejam compatíveis com as condições ecológicas e capazes de incorporar as identidades étnicas e seus respectivos valores culturais. (CAPORAL; COSTABEBER, 2000, p. 21.)

Diante das contradições do modelo econômico vigente, a continuidade da acumulação capitalista só é possível mediante a continuidade da exploração e da contaminação da natureza. Assim, já não se trataria, simplesmente, de um problema de reprodução das condições de produção, senão que estaríamos frente à ameaça de viabilidade do ambiente social e natural como meio de vida (O'CONNOR, 1990).

A corrente ecossocial apresenta reivindicações de mudanças estruturais profundas na sociedade e de um novo pacto de solidariedade, permitindo a construção de um novo projeto histórico e a busca de novos rumos nas estratégias de desenvolvimento. Ou seja, essa corrente objetiva a busca da sustentabilidade, que podemos entender como a utilização da natureza para sanar as necessidades humanas, mas sem exterminar a biodiversidade 
existente. Na agricultura, há ainda o resgate dos saberes e valores tradicionais dos agricultores, no que a agroecologia aparece como exemplo.

Essas duas correntes, constantemente combinadas no discurso contemporâneo de desenvolvimento sustentável, incitam políticas públicas capazes de promover a exploração da natureza sem exterminá-la.

Com isso, o Plano de Desenvolvimento de Assentamento, principal documento regulador do assentamento rural, deve contemplar a questão da sustentabilidade do assentamento com práticas adequadas de manejo de solo e, sobretudo, de água, que visem à garantia da disponibilidade, acessibilidade e qualidade desta para a população assentada.

Contudo, nos modelos de assentamentos rurais existentes em grande parte do país, nem sempre o assentado é de origem camponesa e possui o conhecimento de como explorar a terra sem exauri-la, cabendo aí a atuação do Incra em disponibilizar assistência técnica e projetos de educação ambiental, pois no próprio PDA de cada assentamento fica definida a elaboração de projetos educacionais que contemplem uma produção agrícola em harmonia com a natureza.

No entanto, os sistemas produtivos difundidos por órgãos e técnicos agrícolas, a partir dos estudos realizados pelo Incra, procuram promover um aumento da produtividade que acarreta maior exploração da terra e, em consequência, o uso mais intensivo da água, que nos assentamentos de reforma agrária é gerenciada de maneira distinta das demais propriedades rurais, pois, neles, não existe uma legislação específica que regule o seu uso e gerenciamento.

Assim, o PDA torna-se um instrumento de gerenciamento, por meio dos levantamentos realizados, a fim de evitar conflitos e divergências entre os próprios assentados, visando ao desenvolvimento socioeconômico do PA sem comprometer a diversidade natural existente. 


\section{A ÁGUA COMO ELEMENTO ESSENCIAL NA PRODUÇÃo AGRÍCOLA E OS CONFLITOS ATUAIS PELA SUA APROPRIAÇÃo NO MUNICÍPIO DE UBERLÂNDIA-MG}

A questão da sustentabilidade ambiental perpassa diversos segmentos da questão agrária no Brasil. Seja na agricultura empresarial ou na agricultura familiar, a natureza ora aparece como entrave, ora como possibilidade de desenvolvimento econômico. Contudo, fator decisivo na produção agrícola é a água, que, na atualidade, passa por inúmeros debates a respeito da cobrança ou não pela sua utilização.

Os usos dados à água geram debates e envolvem concepções distintas; a polêmica se insere na dominação da sua gestão por agentes econômicos uma vez que tal elemento natural e sua utilização devem ser do alcance de todos, e não objetos de apropriação e uso de poucos.

Esse debate envolve, ainda, a compreensão de que a modernização de técnicas agrícolas e a expansão do agronegócio determinam o controle da utilização das fontes hídricas no espaço rural e das comunidades que são diretamente afetadas por tal dominação. A partir dessa problemática, pode-se identificar a natureza dos conflitos que envolvem a utilização da água como um recurso natural e os atores envolvidos nessa questão: os agentes econômicos e as comunidades rurais. Uma vez que tal recurso se torne um bem pago, ou até mesmo que o seu uso se torne uma impossibilidade por falta de gerenciamento adequado para a captação, torna-se inevitável o surgimento de conflitos para sua utilização igualitária.

Porém, a água não é como os demais elementos da natureza, ela não é uma matéria-prima, ela é, essencialmente, um bem ambiental que, na atualidade, vem se tornando um bem econômico. O uso da água deve ser compreendido a partir da sua universalidade, já que tal elemento é essencial para todas as práticas humanas na Terra, sendo primordial tanto para as atividades urbanas quanto para as rurais.

Na mesorregião do Triângulo Mineiro/Alto Paranaíba, onde se encontra o município de Uberlândia, existe o domínio dos Cerrados, o segundo maior domínio morfoclimático brasileiro. Sendo essa região predominante de áreas 
de chapadas, é comum um relevo plano suavemente ondulado, que facilita e favorece a mecanização, além de ser abundante em rios e água subterrânea, um dos maiores mananciais hídricos do país, proporcionando intensa captação de água, principalmente para irrigação das lavouras.

No Cerrado, atualmente, o que chama a atenção é a grande quantidade de água utilizada na produção de grãos (café, soja, milho).

É importante compreender que as características físico-ambientais do Cerrado muito favoreceram a expansão da produção agropecuária nos novos padrões da agricultura tecnificada, pautada no modelo tecnológico da "Revolução Verde".

A modernização agrícola brasileira das décadas de 1960 e 1970 impactou consideravelmente as áreas do Cerrado, reconfigurando esse espaço a fim de inseri-lo no novo padrão tecnológico que estava prevalecendo, alterando substancialmente as relações de trabalho até então existentes no campo. O Cerrado, que era constituído por uma vasta e rica diversidade de fauna e flora - além de histórias e culturas de seus povos tradicionais -, passou por intensas transformações e hoje se configura como o domínio natural mais devastado do país.

Além disso, conforme afirma Porto-Gonçalves (2006, p. 427):

No Brasil, o avanço do agronegócio, sobretudo no Planalto Central com suas chapadas extensas e planas, não teria o sucesso econômico de curto prazo que vem obtendo, não fossem desenvolvidas as técnicas de captação de água em grandes profundidades que tornaram possível agricultar aquelas regiões antes ocupadas pelos cerrados e pelas populações que pertencem por gerais-terras, que pertencem a todos. [...] Sem água nenhum cultivo é possível, e esse se constituía num dos principais fatores limitadores do cultivo nas chapadas no Planalto Central [...] (PORTO-GONÇALVES, 2006, p. 427).

Com a política agrícola do Programa de Desenvolvimento dos Cerrados (PRODECER) ${ }^{6}$, que buscava promover o "desenvolvimento" do Cerrado mineiro

\footnotetext{
${ }^{6}$ O PRODECER foi o projeto que expressou com maior força a relação entre Estado e iniciativa privada. O projeto foi um marco das relações entre estas duas nações: de um lado o Brasil, com o espaço a ser apropriado, a mão de obra disponível e a carência de recursos financeiros; do outro o Japão, com o capital e o interesse em criar excedentes produtivos de grãos, diminuir
} 

Assentamentos de Reforma Agrária do Município de Uberlândia-MG, pp. 63-94

por meio de incentivos governamentais em parceria com empresas privadas, o Estado brasileiro colocou nas mãos de grandes proprietários rurais extensas áreas dessa região com o intuito de produzir para exportação.

Tal processo contribuiu para o aumento da concentração de terras, representada por grandes propriedades e latifúndios que hoje dedicam suas atividades quase que exclusivamente à monocultura, principalmente para a produção de matérias-primas para suprir as necessidades do atual modelo energético brasileiro.

A questão agrária, hoje, não pode ser dissociada da questão da sustentabilidade ambiental. As regiões de maior concentração de água, terra, minério e biodiversidade têm se tornado alvos de disputas políticas e econômicas (CLEPS JR., 2012).

Em Minas Gerais, os conflitos pela água vêm aumentando a cada ano. São conflitos associados à falta de água no norte do estado, ao represamento feito por Pequenas Centrais Hidrelétricas ( $\mathrm{PCHs}$ ) e à distribuição e utilização desigual desse recurso em diversas regiões do estado.

O Gráfico 1 apresenta a evolução dos conflitos por terra e água existentes no estado, ressaltando a problemática da água que, atualmente, se insere nas disputas territoriais.

sua dependência por recursos de países do mundo desenvolvido e aumentar sua presença nos países em vias de desenvolvimento. A implantação do projeto se deu por meio das três etapas de colônias de produção (PRODECER I, II e III) (PESSÔA, 1988). A primeira fase do PRODECER beneficiou a região sul dos Cerrados, mais especificamente o Estado de Minas Gerais. A segunda, a área central dos Cerrados, nos estados de Minas Gerais, Goiás, Mato Grosso, Mato Grosso do Sul e Bahia. A terceira etapa do Programa teve início em 1996, quando foi implantado nos municípios de Pedro Afonso (TO) e Balsas (MA). O principal instrumento do programa é o crédito supervisionado, com linhas de financiamento abrangentes, empréstimos fundiários para investimentos, despesas operacionais e assistência ao colono (RODRIGUES; VASCONCELOS; BARBIERO, 2009). 
Gráfico 1: Minas Gerais - Evolução dos conflitos de terra e pela água

(2001-2010)

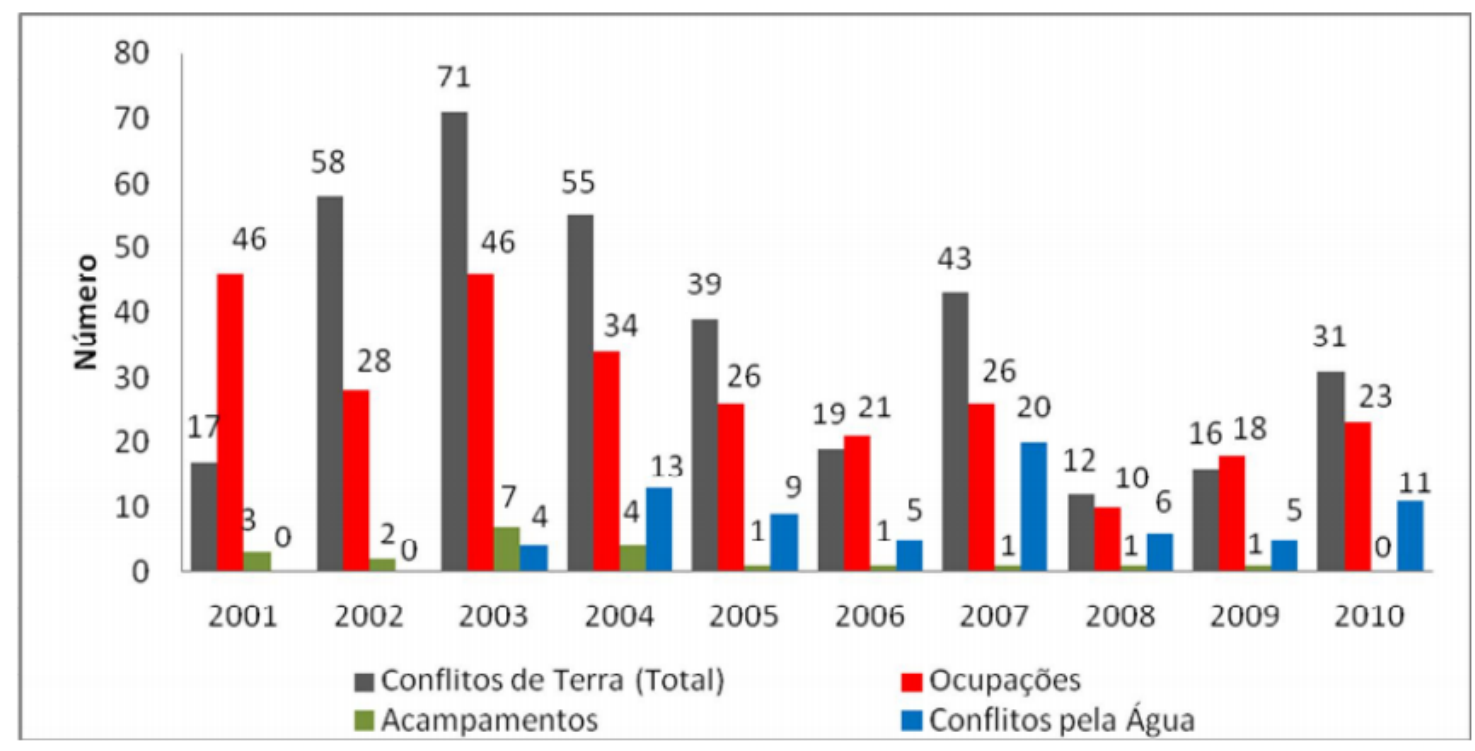

Fontes: CPT/DATALUTA-NERA-LAGEA, 2010. ${ }^{7}$

Org.: CLEPS JÚNIOR, J.

Os conflitos pela água, em Minas Gerais, vêm aumentando, desde 2003. Observamos que os anos de conflitos mais intensos foram 2004 e 2007, tendo os valores oscilado nos demais anos. Tais registros foram coletados pela Comissão Pastoral da Terra (CPT), organização que documenta e analisa os conflitos no campo brasileiro e que, em específico, registra detalhadamente os conflitos por terra, água, trabalhistas, ocupações, acampamentos, manifestações, assassinatos, entre outros que ocorrem anualmente no meio rural $^{8}$. No ano de 2007, registrou-se o maior número de conflitos pela água,

\footnotetext{
7 Os dados a respeito dos conflitos por terra, número de acampamentos e ocupações foram encontrados no Relatório da Luta pela Terra (Dataluta) do ano de 2010. Já os dados de conflitos por água, nos relatórios anuais disponíveis no site da Comissão Pastoral da Terra (CPT).

8 "A Comissão Pastoral da Terra (CPT) nasceu em junho de 1975, durante o Encontro de Pastoral da Amazônia, convocado pela Conferência Nacional dos Bispos do Brasil (CNBB), e realizado em Goiânia (GO). Inicialmente a CPT desenvolveu junto aos trabalhadores e trabalhadoras da terra um serviço pastoral. [...] No período da ditadura, o reconhecimento do vínculo com a CNBB ajudou a CPT a realizar o seu trabalho e se manter" (CPT, 2010). A organização "também atua junto aos trabalhadores assalariados e aos boias-frias, que conseguiram, por algum tempo, ganhar a cena, mas que enfrentam dificuldade de organização e articulação. [...] Em cada região, o trabalho da CPT adquiriu uma tonalidade diferente de acordo com os desafios que a realidade apresentava, sem, contudo, perder de vista o objetivo maior de sua existência: ser um serviço à causa dos trabalhadores rurais, sendo um suporte para a sua organização. [...] a CPT é também uma entidade de defesa dos Direitos Humanos ou uma Pastoral dos direitos dos trabalhadores e trabalhadoras da terra" (Idem). Os dados levantados pela CPT são divulgados anualmente no Caderno Conflitos no Campo, na página eletrônica da organização, sob a forma de tabelas, contemplando as variáveis obtidas em levantamentos primários e secundários em revistas, jornais de circulação local, estadual e
} 

Assentamentos de Reforma Agrária do Município de Uberlândia-MG, pp. 63-94

mostrando que a questão do acesso e disponibilidade desse recurso consolidase nos debates atuais da sustentabilidade. De acordo com os estudos da CPT, metade dos conflitos está relacionada ao uso e preservação da água. Conforme é possível observar ainda no Gráfico 1, há uma redução dos conflitos de terra após 2003, em Minas Gerais, e um aumento crescente dos conflitos pela água.

A disputa pelo controle e uso da água possui, no Triângulo Mineiro/Alto Paranaíba, diversos representantes provenientes de camadas sociais distintas que lutam pelo direito de usufruir um bem natural e abundante na região. Tais setores são representados, sobretudo, pelo agronegócio e empresas privadas.

Entende-se que a questão da água é essencial tanto para o agronegociante quanto para o camponês, pois, sem água, não existe produção, sendo esse recurso de vital importância para a garantia da produtividade da terra. Entretanto, é a partir do mau uso e apropriações desiguais que se estabelecem os conflitos.

Porto-Gonçalves (2006) afirma que os Cerrados, onde atualmente reina - agronegócio, possuem as maiores reservas hídricas do país, bastando observar que é de lá que partem importantes rios para diferentes bacias hidrográficas brasileiras, além de serem, na atualidade, palco de inúmeros conflitos provenientes da expropriação de terras e concentração fundiária existentes. Seguindo suas teorizações:

Um dos conflitos ambientais mais intensos vividos nessas regiões do planalto central está relacionado à questão da água, não pela sua escassez, mas sim aos conflitos de classe por apropriação e expropriação de terras e águas (PORTOGONÇALVES, 2006, p. 428).

Já nos assentamentos de reforma agrária, a água, embora de suma importância, é bem diferente da "terra". Esta tem um estatuto bastante claro

nacional, boletins e publicações de diversas instituições, partidos, órgãos governamentais e núcleos de pesquisa, como a Rede DATALUTA - Banco de Dados da Luta pela Terra. Em Minas Gerais, o projeto DATALUTA é coordenado pelo coautor e responsável pelas pesquisas que originaram o presente artigo. 
para os assentados, sendo apropriada de forma individual (o lote) ou coletiva (como ocorre em reserva ambiental) (SIDERSKY, 2008). As regras de uso da terra "coletiva" vão surgindo e não parecem colocar grandes problemas, a princípio (OSTROM, 1990; CUNHA, 2004).

Em áreas de relevo de chapada, como ocorre no município de Uberlândia, lotes fixados no seu topo dificilmente obtêm água de forma fácil. Espera-se que o assentado que se encontre nessa situação possua poços já perfurados em seu lote ou infraestrutura instalada capaz de captar água em áreas mais baixas. Já o assentado que possui lote em áreas baixas (áreas de vale), próximas a cursos d'água, será beneficiado pela localização geográfica.

Situações assim são mais comuns do que imaginamos e, muitas vezes, geram conflitos entre os camponeses, sobretudo em assentamentos localizados em áreas extensas, que possuem diferenças topográficas entre os lotes.

Em um assentamento, a instalação de um sistema global de captação de água não é uma tarefa simples. É necessário dimensionar e equacionar a distribuição entre as diferentes necessidades. Sendo armazenada por meio de açudes, cisternas e tanques, é necessário também pensar na possibilidade do seu esgotamento. Em geral, o uso final tende a ser familiar, mas aquilo que é necessário para dar acesso ao recurso, frequentemente tem um caráter "coletivo" (SIDERSKY, 2008).

Esse conjunto de fatores nos leva a definir a gestão da água como instrumento de consolidação e melhoria dos sistemas produtivos (SIDERSKY, 2008), ou seja, há uma busca pela segurança hídrica que é pressuposto básico para a segurança e/ou soberania alimentar.

Segurança hídrica, conforme determinado pela Organização das Nações Unidas (ONU), diz respeito à 
Capacidade de uma população salvaguardar o acesso sustentável a quantidades adequadas e de qualidade aceitável de água para manter os meios de sustento, o bem-estar humano e o desenvolvimento socioeconômico, para garantir a proteção contra a contaminação da água e os desastres a ela relacionados, e para preservar os ecossistemas em um clima de paz e estabilidade política (ONU, $2013^{9}$ apud CARVALHO, 2013).

O acesso à água de qualidade e em quantidade suficiente é um direito universal, isto é, de todos. No Brasil, a Lei $n^{\circ}$ 9.433/97, que instituiu a Política Nacional de Recursos Hídricos e o Sistema Nacional de Gerenciamento de Recursos Hídricos (SINGREH), reafirma o direito à água das gerações presentes e futuras e a necessidade de sua utilização racional e integrada.

Essa lei contempla a gestão da água por meio de unidades de planejamento, determinada pela bacia hidrográfica. Essa forma de planejamento visa ao uso adequado da água, e transfere para o nível federal a responsabilidade pelo gerenciamento dos cursos hídricos, já que uma bacia hidrográfica não se encontra exclusivamente dentro dos limites municipais e/ou estaduais, sendo uma unidade de planejamento que não obedece aos limites políticos estabelecidos.

Por ser um bem essencial à vida e à sociedade, a água é um bem público que não está no domínio de nenhum município ou estado em particular, sendo imprescindível regular a sua gestão por meio de políticas públicas eficazes, que contemplem a proteção das fontes naturais, a conservação quantitativa e qualitativa das águas, bem como seu uso racional e distribuição igualitária. Chegamos, assim, à segurança hídrica, essencial à qualidade de vida das populações e à produção econômica.

De acordo com Carvalho (2003),

\footnotetext{
${ }^{9}$ UN-WATER. Water Security \& the Global Water Agenda: a UN-Water analytical brief. United Nations University Institute for Water, Environment \& Health: Hamilton (Canada), 2013.
} 


\begin{abstract}
A Constituição Federal estabelece o direito ao meio ambiente ecologicamente equilibrado como um direito humano fundamental, ao delimitá-lo como essencial à sadia qualidade de vida, relacionando o conteúdo do art. 225 da Constituição Federal ao artigo 5. ${ }^{\circ}$, que estabelece os direitos e garantias individuais e coletivas. Nesse sentido, a água também pode ser considerada um direito fundamental da pessoa humana, devendo receber a proteção jurídica condizente com a sua relevância para sobrevivência digna do ser humano.

Assim, todos possuem direito de acesso e uso às águas, desde que respeitada sua condição de bem público e as normas legais a ela pertinentes, devendo os interesses privados, setoriais e econômicos serem subordinados aos interesses sociais e ambientais.
\end{abstract}

Na agricultura, a produção deve ser baseada em uma utilização adequada da água. A autossuficiência de um agricultor só é conseguida por meio da segurança hídrica, pois uma terra sem acesso a água não pode produzir e, sendo este um elemento básico e imprescindível para a produção agrícola, a sua falta ou dificuldade de acesso compromete não apenas a produção, mas a própria vida do agricultor.

\title{
(IN)SEGURANÇA HÍDRICA E O DESAFIO DE PRODUZIR EM ÁREA SEM ACESSO À ÁGUA: CONSIDERAÇÕES SOBRE OS PAS FLORESTAN FERNANDES, ZUMBI DOS PALMARES, NOVA TANGARÁ E DOM JOSÉ MAURO EM UBERLÂNDIA-MG
}

A água é um bem imprescindível, tanto para o ambiente urbano como para o rural. Apesar da sua utilidade no espaço rural, as formas de captação e a quantidade utilizada variam, de uma propriedade para outra.

Nos assentamentos de reforma agrária estudados nesta pesquisa, o uso da água se destina, quase que exclusivamente, ao consumo humano e dessedentação animal. A atividade agrícola, que exige quantidade de água suficiente para produzir, fica comprometida. Os assentados de reforma agrária ficam legados a sua própria sorte, ora investindo recursos próprios para a instalação precária de meios produtivos e de captação de água, ora esperando o financiamento dos programas governamentais de fomento da agricultura familiar. 

Assentamentos de Reforma Agrária do Município de Uberlândia-MG, pp. 63-94

Nas pesquisas de campo realizadas no ano de 2012 com o objetivo de estudar a questão da água em quatro assentamentos de reforma agrária no município de Uberlândia-MG, foram constatados problemas relacionados à obtenção, controle e distribuição da água. Os assentamentos estudados foram: PAs Florestan Fernandes, Zumbi dos Palmares, Nova Tangará e Dom José Mauro, representados no Mapa 1 pelos números 2, 3, 6 e 7, respectivamente, e cuja localização está próxima das BRs 365 e 497.

Mapa 1: Localização dos projetos de assentamento no município de Uberlândia-MG

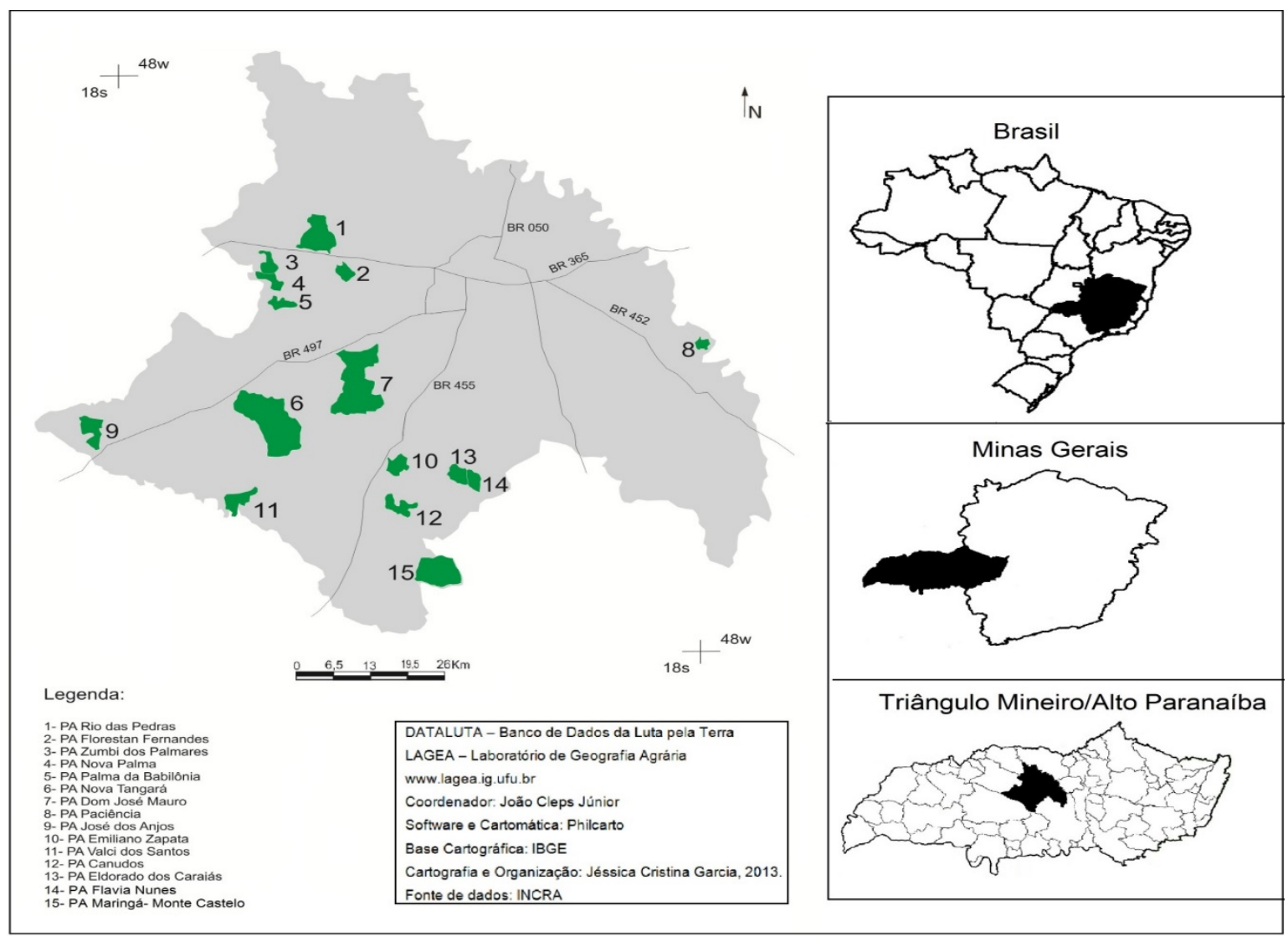

Org.: GARCIA, J.C., 2013.

Ao considerarmos que a modernização da agricultura desencadeou fatores negativos para a agricultura camponesa, temos que pensar nas estratégias de resistência do campesinato, que hoje se territorializa por meio das ocupações de terras, manifestações em sedes de municípios e lutas em 
favor de uma reforma agrária que promova a distribuição de terras e garanta condições de sobrevivência para quem vive da terra. O camponês expropriado busca, na posse da terra, formas de garantir condições mínimas de sobrevivência. Os trabalhadores se unem na tentativa de resgatar seus direitos e cidadania muitas vezes não obtidos nas periferias das grandes cidades.

Após a conquista da terra, inicia-se uma nova etapa na consolidação do processo de reforma agrária; a terra precisa produzir e garantir a reprodução da existência dos assentados. A água, no entanto, como elemento básico essencial a toda produção agrícola, muitas vezes não se encontra em quantidade, qualidade e disponibilidade.

Nos PAs pesquisados, foram encontrados problemas quanto à captação, distribuição, uso e qualidade da água. Apesar de possuírem uma diferença locacional - mesmo que mínima, já que se encontram no mesmo município -, os assentamentos em questão compartilham da mesma realidade do precário acesso à água, dentre outras dificuldades.

Nos quatro assentamentos pesquisados, os camponeses produzem gêneros alimentícios para o próprio consumo, produtos hortifrutigranjeiros cuja comercialização, em geral, restringe-se apenas ao interior do assentamento. No PA Nova Tangará, há maior diversificação produtiva, questão considerada importante para a consolidação de um assentamento rural de referência na produção, mesmo com acesso limitado da água para o desenvolvimento de suas atividades.

Com o apoio do Programa Nacional de Fortalecimento da Agricultura Familiar (PRONAF), os assentados têm conseguido comercializar a sua produção graças a obtenção da Declaração de Aptidão ao Pronaf (DAP), documento necessário para a venda de seus produtos com o selo da reforma agrária.

Além da organização (ou não) em movimentos sociais mais amplos, como é o caso do Movimento dos Trabalhadores Rurais Sem Terra (MST), os assentados se organizam, principalmente, em forma de associações, e elegem representantes para tratar de questões diversas dentro do assentamento, em que a Empresa de Assistência Técnica e Extensão Rural (Emater) ou uma empresa privada contratada pelo INCRA oferece a assistência técnica mínima 

Assentamentos de Reforma Agrária do Município de Uberlândia-MG, pp. 63-94

para direcionar as atividades produtivas.

Os problemas básicos dos lotes são diversos. Em sua maioria, por serem muito acidentados, sofrem como a ação das chuvas e do intemperismo, tendo sido encontrados lotes com erosões profundas e até voçorocas, comprometendo a qualidade do solo e a produção, assim como os mananciais hídricos presentes na região.

Os assentados que possuem lotes próximos aos mananciais - fato que os torna privilegiados - muitas vezes utilizam rodas d'água (Figura 1) para a sua captação e bombeamento. Em contrapartida, os que não possuem condição alguma para usufruir de um justo sistema de água utilizam-se de técnicas precárias de captação.

Figura 1: Utilização da roda d'água para bombeamento de água no assentamento Zumbi dos Palmares, Uberlândia-MG

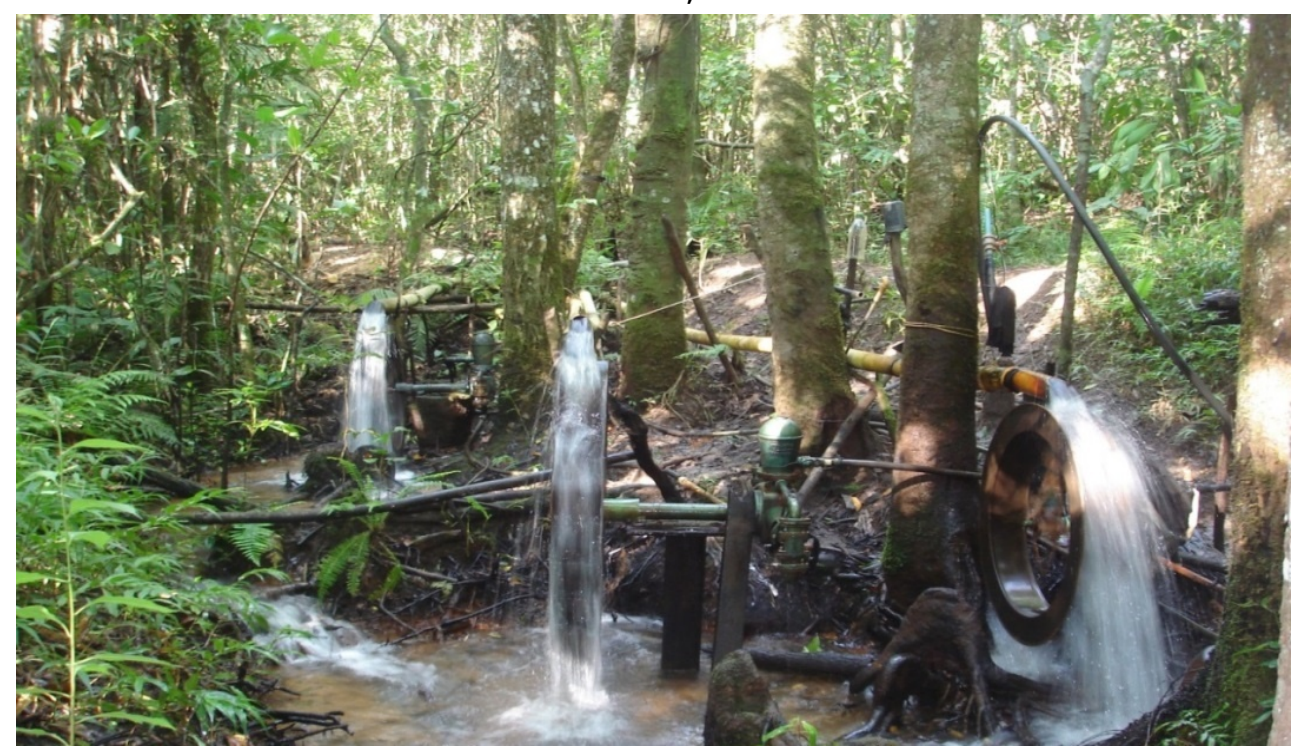

Foto: GARCIA, J.C.

Fonte: Acervo dos autores, 2012.

O INCRA é o órgão encarregado das perfurações de poços artesianos, instalações de encanamentos e rede de distribuição de água. Em alguns casos, entretanto, os assentados não conseguem utilizar a infraestrutura instalada. É o que acontece no PA Zumbi dos Palmares, com 22 famílias, onde existem dois poços artesianos perfurados, mas um deles está inutilizado há quatro 
anos e o outro teve os seus encanamentos destruídos após a explosão da bomba que era inadequada para suportar o poço. As duas caixas d'água ali existentes, com capacidade para 17 mil litros cada uma, estão abandonadas (Figura 2).

Dessa forma, a maioria dos assentados construiu sua própria cisterna ou perfura mini poços com seus próprios recursos, sem ajuda governamental. Apesar do esforço, contudo, a água captada só é utilizada para o abastecimento humano e dessedentação animal, já que para irrigação de lavouras é preciso uma quantidade bem maior que só a cisterna comporta. Além disso, existem, ainda, dentro do assentamento, dois córregos cujas nascentes estão próximas a uma granja de suínos, o que preocupa os assentados quanto à qualidade dessa água.

Figura 2: Caixa d'água abandonada no PA Zumbi dos Palmares, Uberlândia -MG

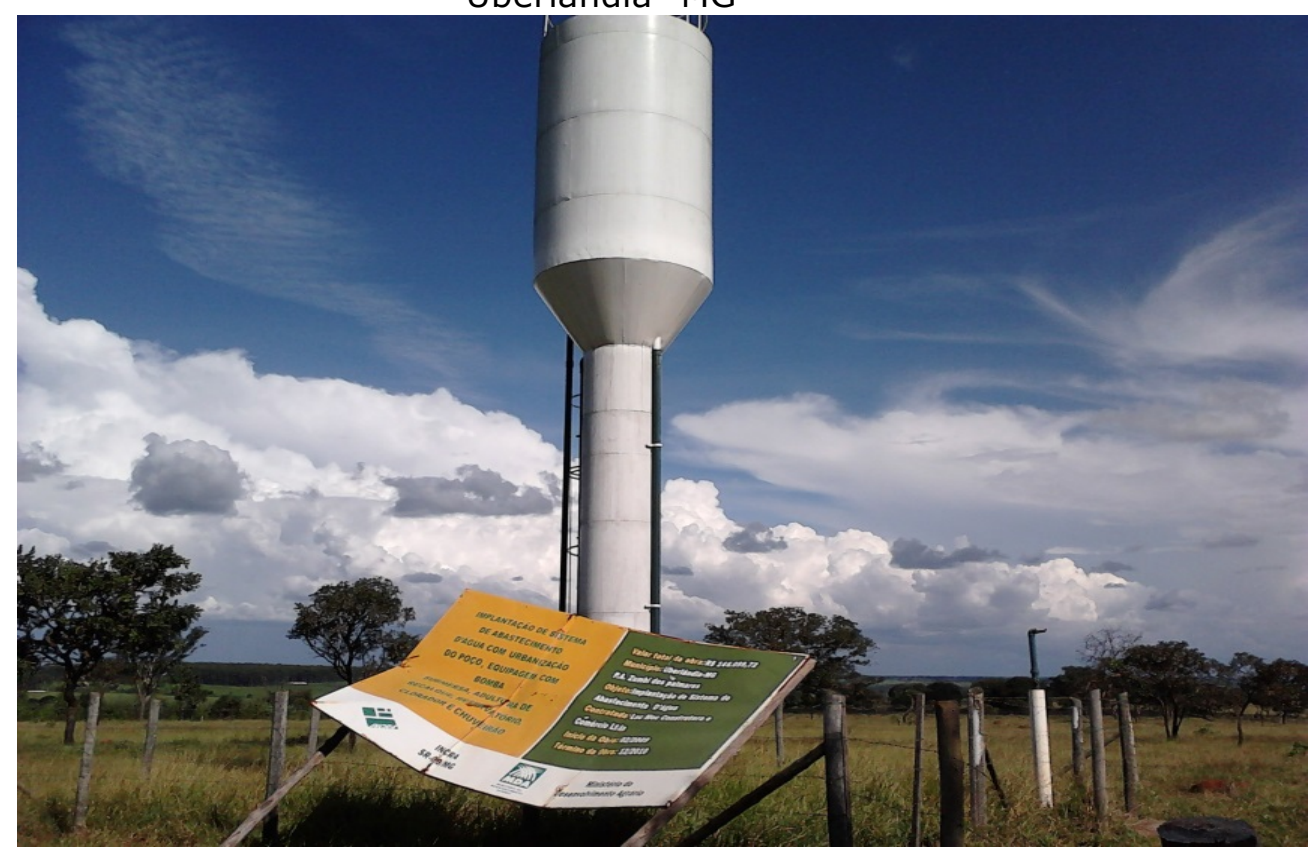

Foto: GARCIA, J.C.

Fonte: Acervo dos autores, 2012.

O caso mais crítico, porém, é o do PA Tangará, localizado próximo à BR 497, saída para o município de Prata, onde existem seis poços artesianos perfurados pelo INCRA, mas apenas dois são utilizados porque os demais não estão equipados. Verifica-se, contudo, que das 250 famílias, 187 não possuem acesso à água, e, enquanto um poço serve 16 famílias, outros dois atendem 47, num assentamento criado há cerca de oito anos (GARCIA, 2013). A 

Assentamentos de Reforma Agrária do Município de Uberlândia-MG, pp. 63-94

maioria dos lotes possui cisterna para armazenar a água da chuva e os que estão próximos aos cursos d'água canalizaram-na em alguns trechos.

Outro assentamento estudado, O PA Dom José Mauro - com 205 famílias, também localizado próximo à BR 497, na antiga estrada de Miraporanga -, não possui poços artesianos, mas doze represas que abastecem os assentados, além do rio Douradinho, que tem uma de suas nascentes localizada dentro do projeto (Figura 3). Apesar de ser abastecido por doze grandes represas, o PA está localizado próximo ao antigo aterro sanitário do município, e há risco de que parte da água que passa pelo assentamento esteja contaminada.

Grande parte dos assentados possui cisternas, mas, como ficou perceptível no decorrer da pesquisa, por ser um PA criado em 2009, há pouca infraestrutura instalada. As famílias ainda aguardam, por exemplo, pelo crédito habitação, cedido pelo Governo Federal, que subsidia a construção das casas. Como as famílias ainda não receberam esse financiamento, via Banco do Brasil, não encontramos casas no interior do assentamento.

Figura 3: Nascente do rio Douradinho no PA Dom José Mauro, Uberlândia-MG

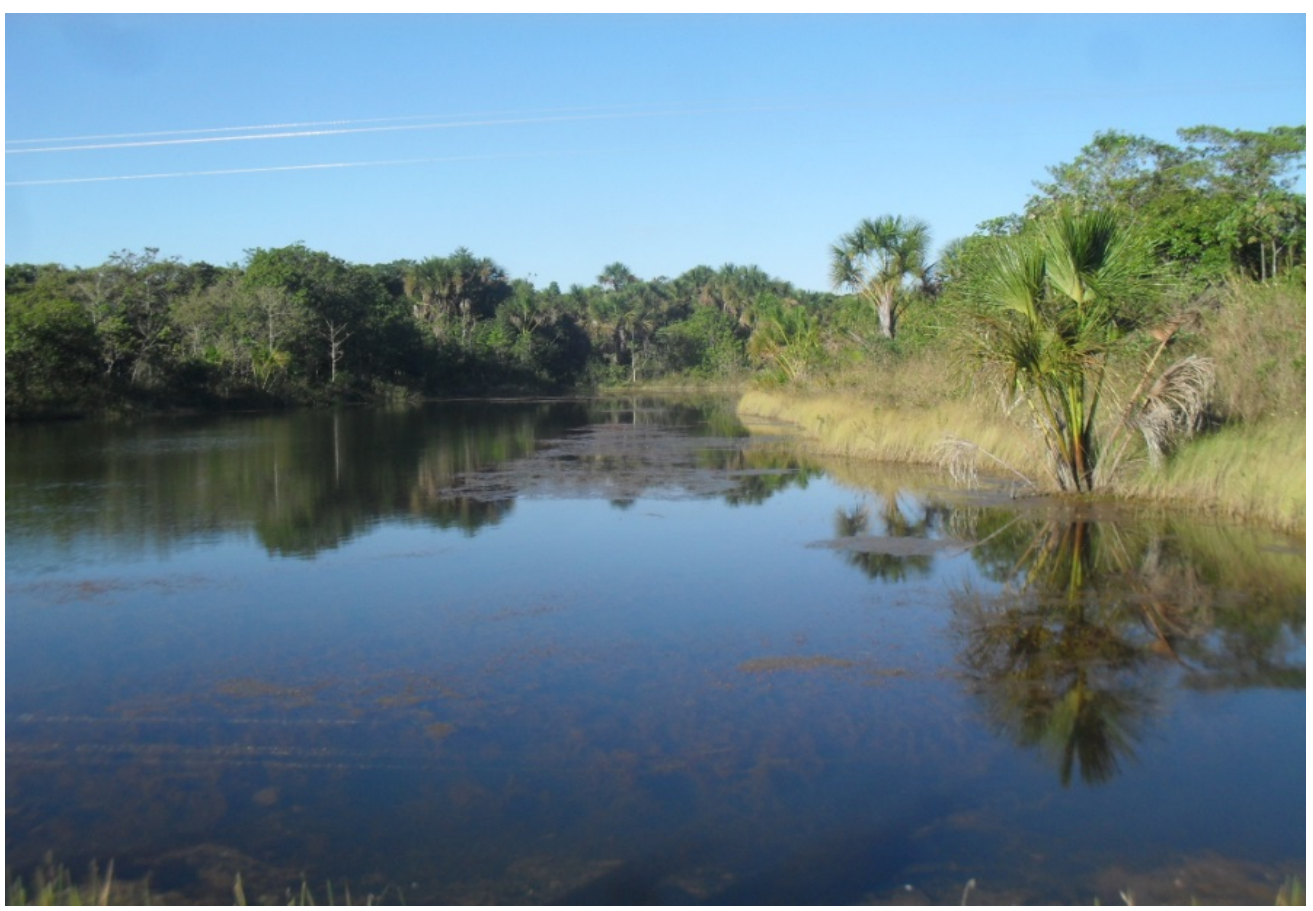

Foto: GARCIA, J.C.

Fonte: Acervo dos autores, 2012. 
Na Figura 3, é possível observar uma das nascentes de um dos rios mais importantes do município de Uberlândia, o rio Douradinho, que proporciona o abastecimento dos assentados do PA Dom José Mauro, mesmo com infraestruturas precárias de captação de água do rio. No Douradinho, os assentados também obtêm alimento por meio da pesca de várias espécies de peixe, principalmente a traíra (Figura 4).

Figura 4: Pesca no rio Douradinho no assentamento Dom José Mauro, Uberlândia-MG

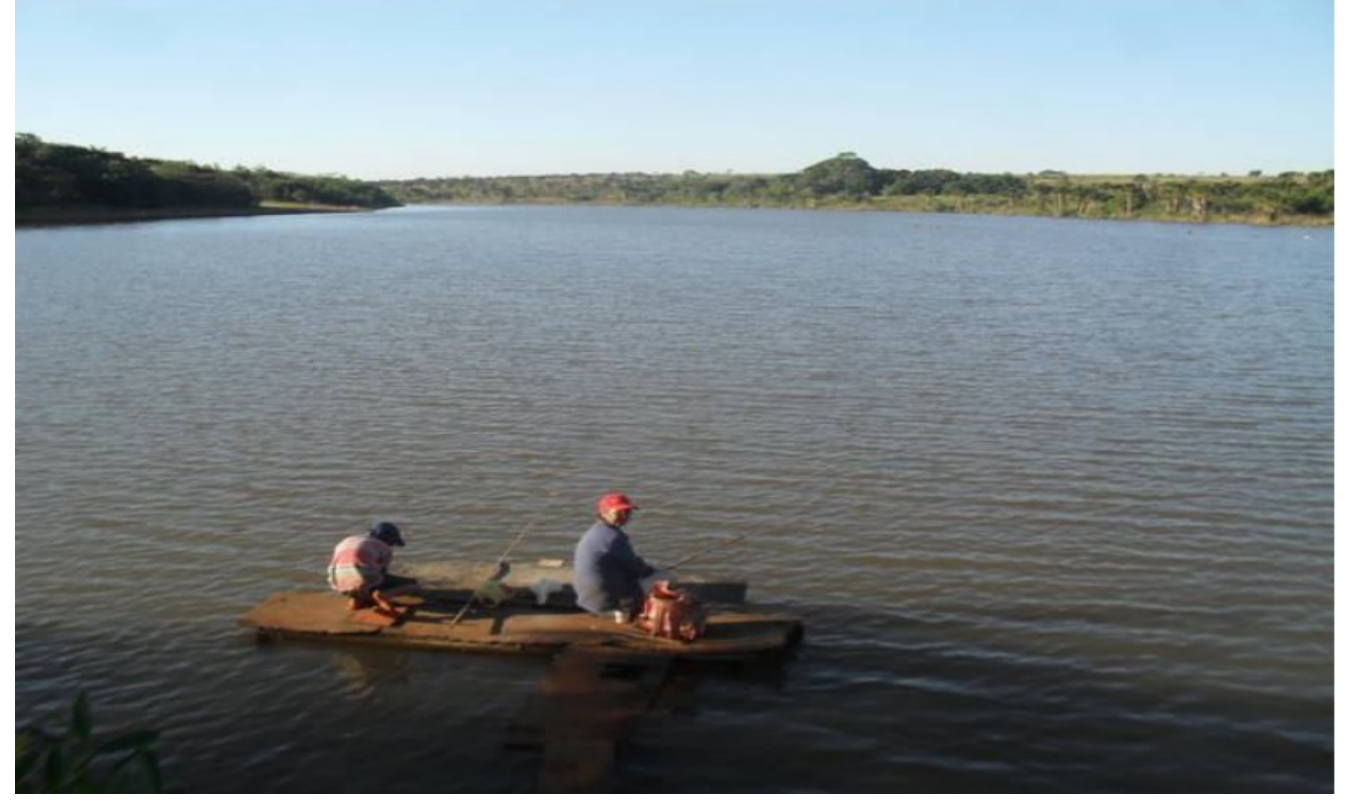

Foto: GARCIA, J.C.

Fonte: Acervo dos autores, 2012.

Com isso, o rio que atravessa todo o assentamento é sinônimo de vida para grande parte dos assentados, que tentam construir suas casas próximo de suas margens. Neste PA, a espera pelos financiamentos que possibilitarão a construção de casas e plantio das lavouras é amenizada pela presença do rio, que tem se mostrado muito importante para os assentados. Contudo, a proximidade com 0 antigo aterro sanitário deixa as famílias apreensivas quanto à qualidade do que eles consomem.

Os planos de desenvolvimento dos assentamentos deveriam atentar para essas particularidades existentes em cada projeto de reforma agrária. 0 desinteresse e a urgência de criação de PAs, entretanto, fazem com que muitos deles fiquem esquecidos pelo poder público. 
(In)Segurança Hídrica e o Desafio de Produzir sem Acesso à Água em Assentamentos de Reforma Agrária do Município de Uberlândia-MG, pp. 63-94

Conforme Bezerra (2011), a luta pela terra não pode ser dissociada da luta pela água, pois, deve-se ressaltar, em qualquer modelo de produção agrícola, seja o agronegócio ou a agricultura camponesa, estes não se efetivam sem a segurança hídrica, ou seja, sem disponibilidade de água abundante. A reprodução da existência de um agricultor passa diretamente pelo acesso à água.

Sem acesso à água não se pode produzir e, sendo este o recurso básico imprescindível para a produção agrícola, a sua falta ou dificuldade de acesso compromete não apenas à produção, mas até mesmo a existência do agricultor. Dessa forma, muitos assentados não conseguem produzir para seu próprio sustento e acabam tendo que buscar formas alternativas de produção e sobrevivência.

Torna-se, assim, evidente a necessidade de políticas e projetos governamentais que mantenham o homem no campo, sobretudo o camponês dos assentamentos de reforma agrária. Há uma busca pela segurança hídrica nos assentamentos rurais. Mais que isso, existe uma clara necessidade de água nos assentamentos, sendo este o elemento primordial na produção que não está sendo disponibilizado de forma abundante e com qualidade adequada para a população que ali se encontra, comprometendo até mesmo a permanência de boa parte deles na terra conquistada.

\section{O CAMPESINATO SE REPRODUZ NA RESISTÊNCIA: A AGROECOLOGIA COMO ALTERNATIVA PARA O USO SUSTENTÁVEL DA ÁGUA EM ASSENTAMENTOS RURAIS}

A modernização da agricultura não eliminou a agricultura camponesa. Ao contrário, o campesinato, hoje, se configura como alternativa ao modelo predatório de agricultura capitalista e vem ganhando destaque na produção dos alimentos orgânicos que fogem à regra da utilização de venenos, adubos e fertilizantes industriais durante o cultivo. De acordo com Oliveira (1982), a agricultura camponesa, mesmo com todos os empecilhos, não deixa de existir. 
Pelo contrário, ela se reproduz e se fortalece na luta pela permanência na terra e pela reforma agrária.

O agronegócio é, na atualidade, o maior oponente dos movimentos de luta pela terra, pelo seu caráter conservador e agroexportador que concentra ainda mais a terra, havendo que se considerar, ainda, os malefícios que esse modelo de produção agrícola causa ao ambiente. Assim, surgiria, na década de 1980, o sistema produtivo agroecológico, como alternativa ao modelo de produção herdado da Revolução Verde.

Pela sua definição, a agroecologia se refere, substancialmente, ao meio natural essencial a toda e qualquer forma de produção agrícola, seja ela convencional ou "alternativa". A essa definição etimológica se relaciona outra, de caráter humano: a agroecologia como área de conhecimento social e culturalmente construída. Nesse sentido, a agroecologia demarca um novo foco de necessidades humanas, orientando a agricultura à sustentabilidade. Assim, ela se concretiza quando, simultaneamente, cumpre com as premissas da sustentabilidade ecológica (manutenção ou melhoria da qualidade dos recursos naturais e das relações ecológicas de cada ecossistema), econômica (potencial de geração de renda, de trabalho, acesso ao mercado), social (inclusão das populações mais pobres e segurança alimentar), cultural (respeito às culturas tradicionais), política (organização para a mudança e participação nas decisões) e ética (valores morais transcendentes).

A agroecologia se insere no debate da sustentabilidade ambiental, em que, na atualidade, há uma busca por formas alternativas de produzir sem exterminar a natureza. Com isso, a agricultura familiar/camponesa aparece como agente nesse processo de desenvolvimento da agricultura ecológica.

Nos assentamentos de reforma agrária são produzidos os alimentos básicos essenciais à sobrevivência dos camponeses e a forma de gerenciamento da terra é, em geral, familiar. Dessa forma, a agricultura camponesa ou familiar é vista como a disseminadora do sistema agroecológico.

Assim, no atual padrão hegemônico de agricultura capitalista, surgem sistemas alternativos que buscam extrair da terra todo seu potencial produtivo sem, contudo, devastar a natureza. Como exemplo do uso sustentável da natureza, temos o uso da água em sistemas alternativos de produção, 
(In)Segurança Hídrica e o Desafio de Produzir sem Acesso à Água em Assentamentos de Reforma Agrária do Município de Uberlândia-MG, pp. 63-94

citando-se aqui a construção de Mandallas, principalmente, em assentamentos de reforma agrária.

O sistema Mandalla, ou Projeto Holístico de Produção e Sustentabilidade Ambiental (baseado na filosofia indiana), é um sistema de irrigação comunitário baseado em canteiros ao redor de uma fonte de água. Numa horta, os canteiros são circulares e os aspersores são feitos com hastes de cotonetes. Nela não há uso de veneno, ou seja, agrotóxicos; o adubo é obtido do esterco de patos, gansos - que vivem no primeiro círculo do cultivo - e peixes - que se distribuem em um tanque bem no meio do cultivo. No centro do sistema está o reservatório de água, no primeiro círculo, as criações e, nos círculos restantes, horta, pomar, e cultivo de grãos. O sistema distribui água uniformemente para plantações diferentes. A irrigação é em forma de círculos concêntricos e com várias culturas integradas, apresentando um custo inferior à irrigação tradicional, e é voltada para os pequenos proprietários ou associações rurais. As figuras 5 e 6 ilustram Mandallas do PA Emiliano Zapata $^{10}$, em Uberlândia-MG, e a produção de alimentos realizada nesse sistema.

Figura 5: Sistema de Mandalla no PA Emiliano Zapata, Uberlândia-MG

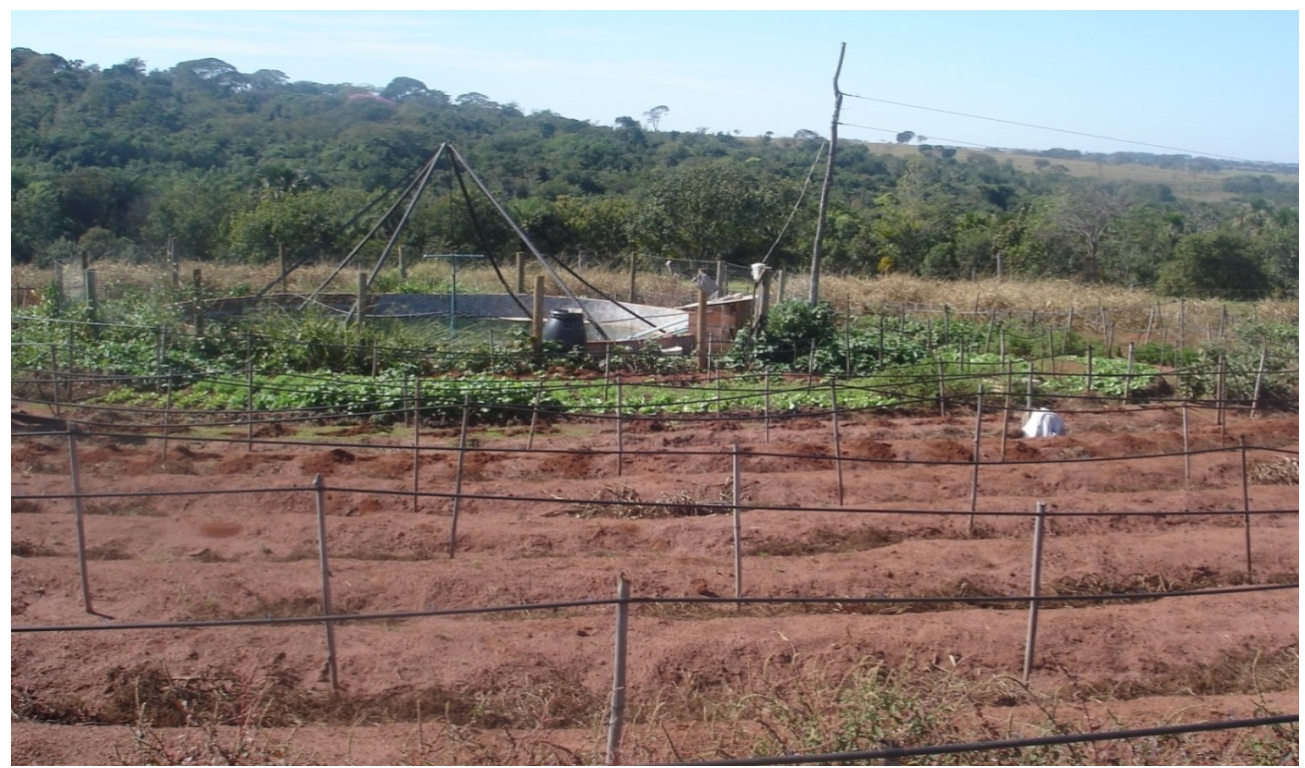

Fonte: Laboratório de Geografia Agrária -LAGEA - 2012.

10 O PA Emiliano Zapata não foi incluído na pesquisa aqui apresentada, contudo, foi visitado em outras ocasiões e tornou-se pertinente utilizá-lo como exemplo e referência da prática do sistema de Mandalla dentre os assentamentos de reforma agrária existentes em Uberlândia. 
Figura 6: Produção de hortaliças no sistema Mandalla no PA Emiliano Zapata, Uberlândia-MG

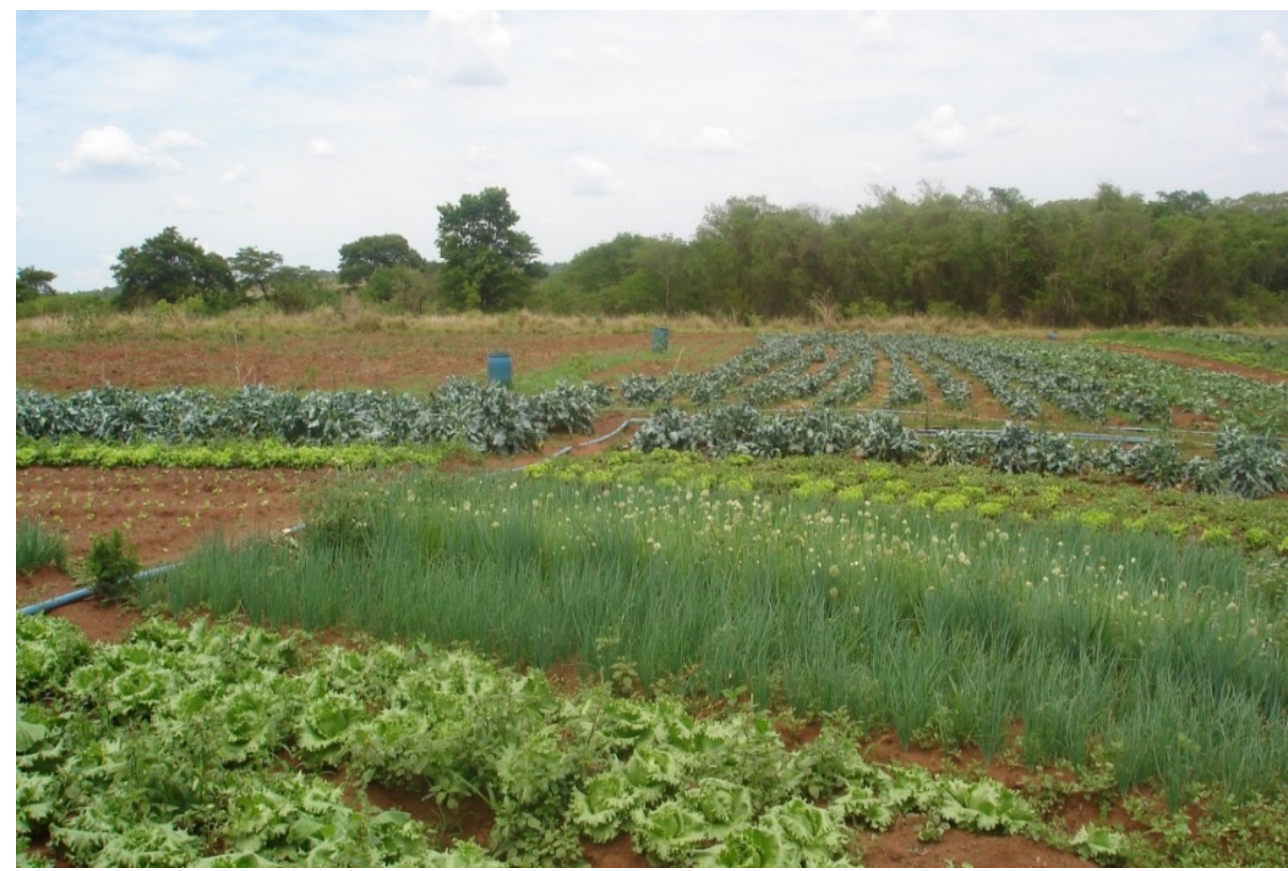

Fonte: Laboratório de Geografia Agrária - LAGEA - 2012.

Além disso, projetos de assentamentos rurais com propostas agroecológicas de desenvolvimento constituem alternativas favoráveis à preservação ambiental em áreas de Cerrado (SOARES; ESPÍNDOLA; PEREIRA; 2007), visto que esse domínio morfoclimático é o mais afetado pela agricultura capitalista e seu modelo de produção agroexportadora, que promove um verdadeiro extermínio de espécies nativas e também de povos e culturas tradicionais.

Assim, surgem alternativas que valorizam a agricultura familiar/camponesa e esta se reproduz por meio da sua resistência aos modelos impostos pela agricultura comercial. Veiga (2000) conclui esse pensamento ao enfatizar que: 
[...] As vantagens de uma estratégia de desenvolvimento rural que priorize a promoção da agricultura familiar começam a ser percebidas pela sociedade brasileira. Principalmente porque 0 Brasil é um país onde a forma de agricultura mais favorecida a patronal - agora está empregando cada vez menos trabalhadores, e engendrando, portanto, cada vez mais concentração de renda e exclusão social. [...] A agricultura familiar é tão mais sustentável (estabilidade, resiliência e equidade) que é impossível imaginar que a sociedade brasileira não venha a se dar conta do preço que está pagando por ter acreditado no mito da maior eficiência da agricultura patronal (VEIGA, 2000, p. 26).

Portanto, verifica-se que os projetos de reforma agrária podem utilizar noções e práticas sustentáveis como alternativa à agricultura capitalista para alcançarem o desenvolvimento socioeconômico. Além disso, tais práticas não agridem a natureza e promovem a otimização de terra e, principalmente, de água, além do aproveitamento de boa parte de tudo o que é produzido em todas as etapas da produção agrícola.

A Mandalla, como técnica de produção de hortaliças, não resolve o problema da insegurança hídrica nos assentamentos. Entretanto, promove a melhor utilização da água em todo o processo produtivo, sendo uma técnica bastante utilizada nos assentamentos visitados, mas que demanda mão de obra e tempo dos camponeses, caracterizando-se como uma técnica produtiva para lotes familiares que possuam disponibilidade de mão de obra.

\section{CONSIDERAÇÕES FINAIS}

A reterritorialização do campesinato, mediante a implementação de assentamentos de reforma agrária, encontra diversas barreiras para se efetivar. As políticas públicas, comumente, priorizam os interesses dos grandes proprietários de terras e do agronegócio, deixando o campesinato sempre à margem dos benefícios, como a infraestrutura dos projetos de assentamento.

Os planos e projetos pensados com o intuito de favorecer a agricultura camponesa geralmente não dialogam com os camponeses, e suas práticas 
permanecem apenas no papel, sem representar melhoria alguma na qualidade de vida das populações que vivem nos assentamentos rurais.

Como elemento básico inerente a qualquer atividade humana, a água, não se encontra em qualidade e disponibilidade aos assentados. A maioria das instalações para captação é precária e pouco eficiente, servindo mais para atender ao consumo humano do que para a produção agrícola.

Com isso, a luta pela terra ganha outros contornos. Os sem-terra lutam pelo direito de permanecer na terra, tendo como bandeira de luta a oposição à forma como o agronegócio e as multinacionais se apropriam da natureza. Tais setores lucram com a agricultura empresarial, com a manipulação da natureza e a visão de que o campo tem que ser moderno e altamente tecnificado. Os movimentos sociais, agora, lutam para continuar na terra e para conseguirem produzir pelo viés da agricultura agroecológica e sustentável. A expansão recente dos empreendimentos do setor sucroenergético confirma a apropriação desigual da água.

Na agricultura camponesa, está a possibilidade de melhorar a qualidade de vida da população do campo, aliada ao uso de tecnologias que agridem menos o ambiente, aqui representada pelo sistema de Mandallas, que busca otimizar o uso da água em locais onde a sua captação e distribuição são feitas de formas precárias, a exemplo dos assentamentos rurais.

Contudo, a reforma agrária encontra ainda diversos obstáculos para se efetivar, faltando uma realização eficaz das políticas públicas básicas existentes, e a questão da segurança hídrica é essencial para a consolidação de assentamentos rurais, visto que o acesso à água é primordial, tanto para a produção agrícola como para a própria existência do camponês.

\section{REFERÊNCIAS}

Albuquerque, F. J. B.; COElho, J. A. P. de; VASCONCElos, T. C. As políticas públicas e os projetos de assentamento. Estudos de Psicologia, Universidade Federal da Paraíba, v. 9 (1), p. 81-84, 2004.

BEZERRA, J. P. P. A água como elemento estruturante na construção de territórios da soberania alimentar. Boletim DATALUTA, Presidente Prudente, abr. 2011. Disponível em: <http://www4.fct.unesp.br/nera/artigodomes/4artigodomes_2011.pdf>. 
(In)Segurança Hídrica e o Desafio de Produzir sem Acesso à Água em Assentamentos de Reforma Agrária do Município de Uberlândia-MG, pp. 63-94

Acesso EM: 21 JUN. 2011.

BRASIL. Lei no 9.433, de 8 de janeiro de 1997. Institui a Política Nacional de Recursos Hídricos, cria o Sistema Nacional de Gerenciamento de Recursos Hídricos.

CAPORAL, F. R; COSTABEBER, J. A. Agroecologia e desenvolvimento rural sustentável: perspectivas para uma nova extensão rural. Agroecologia e Desenvolvimento Sustentável, Porto Alegre, v. 1, n. 1, jan./mar. 2000. p. 1637.

CARVALHO, L. Direito ambiental: insegurança hídrica e o acesso à água. Revista Ecológico, São Paulo, 15 abr. 2013. Disponível em: <http://www.revistaecologico.com.br/noticia.php?id=1197>. Acesso em: 10 ago. 2013.

CLEPS JR., J. Disputas territoriais e agronegócio em Minas Gerais: conjuntura da reforma agrária e diversidade dos conflitos no campo (pesquisa DATALUTA). IN: 21. ENCONTRO NACIONAL DE GEOGRAFIA AGRÁRIA. Uberlândia, 2012. Anais... Uberlândia, 2012.

CPT. O nascimento da CPT. Goiânia, 2010. Disponível em: <http://www.cptnacional.org.br/index.php/quem-somos/-historico>. Acesso em: 02 jul. 2014.

CUNHA, L. H. Da tragédia dos comuns à ecologia política: perspectivas analíticas para o manejo comunitário dos recursos naturais. Raízes, Campina Grande, v. 23, n. 1-2, p. 10-26, 2004.

DATALUTA. Relatório DATALUTA Minas Gerais 2012. Uberlândia: LAGEA/NERA, 2012. Disponível em: <http://www.lagea.ig.ufu.br/relatoriosdatalutaminas.html>. Acesso em: 04 maio 2012.

GARCIA, J.C. Conflitos e práticas dos usos da água por agricultores em projetos de reforma agrária do município de Uberlândia: (in)segurança hídrica e o desafio de produzir em uma terra sem acesso à água. 2013. 80 f. Trabalho de Conclusão de Curso (Graduação em Geografia) - Universidade Federal de Uberlândia, Uberlândia, 2013.

INCRA. Manual dos assentados de reforma agrária. Brasília, 2001, 53 p.

INCRA. Manual operacional de Ates. Brasília, 2008.

INCRA; FAO. Análise dos diagnósticos dos sistemas agrários. Brasília, 1999.

MELLO, P. F. Evasão e rotatividade em assentamentos rurais no Rio Grande do Sul. 2006. 228 f. Dissertação (Desenvolvimento Rural) Universidade Federal do Rio Grande do Sul, Porto Alegre, 2006. Disponível em: <http://www.lume.ufrgs.br/handle/10183/7988>. Acesso em: 05 ago. 2013. 
O' CONNOR, M. El mercadeo de la naturaliza: sobre los infortunios de la naturaleza capitalista. Ecologia Política. Barcelona: Icaria, n. 7, p. 15-34, 1994.

OLIVEIRA, A. U. Modo capitalista de produção e agricultura. São Paulo: Hucitec, 1982.

OSTROM, E. Governing the Commons: the evolution of institutions for collective action. Cambridge: Cambridge University Press, 1990.

PESSÔA, V. L. S. Ação do Estado e as transformações agrárias no Cerrado das zonas de Paracatu e Alto Paranaíba -MG. 1988. Tese (Doutorado em Geografia) - UNESP, Rio Claro, 1988.

PORTO-GONÇALVES, C. W. A globalização da natureza e a natureza da globalização. Civilização Brasileira: Rio de Janeiro, 2006. 420 p.

RODRIGUES, W.; VASCONCELOS, S. J.; BARBIERO, A. K. Análise da efetividade socioeconômica do PRODECER III no município de Pedro Afonso, Tocantins. Pesquisa Agropecuária Tropical, Goiânia, v. 39, n. 4, p. 301-306, out.-dez. 2009.

SANTOS, F. A. Trabalho e educação do campo: a evasão da juventude nos Assentamentos de reforma agrária: o caso do assentamento José Dias. 2006. 147 f. Dissertação (Mestrado em Educação) - Universidade Federal do Paraná, 2006.

SIDERSKY, P. R. Gestão de recursos hídricos e sistemas produtivos: um estudo sobre inovações técnicas e sociais em assentamentos do Alto Sertão da Paraíba. Sociedade e Desenvolvimento Rural, Brasília, v. 2, n. 1, p. 1-24. 2008.

SOARES, J. L. N; ESPÍndolA, C. R; PEREIRA, L. C. Projeto de assentamento rural no cerrado maranhense: uma proposta agroecológica. Revista Brasileira de Agroecologia, [S.I.], v. 2, n. 1, maio 2007.

VEIGA, J. E. Diretrizes para uma nova política agrária. In: BRASIL. Ministério do Desenvolvimento Agrário. Reforma Agrária e Desenvolvimento Sustentável. Brasília, 2000. p. 19-35. 